\title{
Research and Practice on Professional Construction of New Energy Automobile Technology-Wuxi Vocational Institute of Commerce as an Example
}

\author{
Gong Wenzi
}

Wuxi Vocational Institute of Commerce, Wuxi, Jiangsu 214153, China

Keywords: New energy automobile technology; Professional construction; Research and practice; Curriculum system

\begin{abstract}
Regarding the personnel training of vocational colleges as a starting point, through to the analysis on talent demand characteristics of new energy automobile aftermarket, according to the personnel training ideas of modern apprenticeship, a professional training program and curriculum system of new energy have been prepared. The college and enterprise jointly build "Chery new energy automobile marketing and after-sales technical service personnel" training base, and have clarified the function of college-enterprise cooperation in joint construction of a training base, thus to provide reference for the construction of new energy automobile technology in vocational colleges.
\end{abstract}

\section{Introduction}

Energy and environmental problems are the long-term common challenges faced by the international automobile industry. The pattern of global auto industry is facing the fourth round of restructuring, and automobile products will develop toward a safe, energy-saving and environmental protection direction; the concept of "new energy automobiles" has become the focus of the industry, and new energy automobiles have become the research and development target and pursuit among countries. At present, the development of new energy automobiles has become a national strategy, and China's new energy automobile industry faces an once-in-a-lifetime opportunity.

The rapid development of new energy automobile industry is both an opportunity and a challenge for professional construction in vocational colleges. New energy automobiles are different from traditional fuel vehicles in terms of structure, principle, manufacturing, after-sales service, maintenance and diagnostic equipment and so on. Among the vocational colleges with the specialty of new energy automobile open, in addition to retaining the form and content of traditional automobile teaching in the field of new energy automotive automobile, high pressure system safe operation, power electronic technology, motor and control technology and battery technology, etc. shall also be incorporated. The development of new energy automobile industry has put forward higher requirements for talent training in higher vocational colleges. However, the training of talents in current domestic vocational colleges specializing in new energy automobile technology service and marketing is still in its infancy stage, and a serious shortage of high-quality professionals is involved in the new energy automobile aftermarket, which affect the normal development of new energy automotive industry to some extent.

Based on the analysis on talent demand characteristics of new energy automobile aftermarket in this paper, through the enterprise research, and expert argumentation inside and outside universities and colleges, a professional talent training program for new energy automobiles has been prepared to provide reference for related professional construction in vocational colleges.

\section{Talent Demand Characteristics of New Energy Automobile Aftermarket}

Although new energy automobile has developed from traditional vehicle, the demand of new energy automobile for talents is different from that of traditional vehicle. The technicians engaged in new energy automobile aftermarket need not only the technical skills of traditional vehicles, but are also 
required to master the professional knowledge associated with new energy automobile structure, motor driver technology, hybrid power vehicle technology, power system integration and control, fuel cell engine and its auxiliary system, DC/DC converter, power battery and management system, high voltage safety, automobile bus and smart network technology, application and principle of charging station, battery maintenance and charging and other new disciplines and technical aspects; interdisciplinary and inter-disciplinary talents are the talent demand characteristic of the new energy automobile industry.

The implementation program of Jiangsu province for application and popularization of new energy automobiles in the "13th Five-Year Plan" has pointed out: "during the 13th Five-Year Plan" period, more than 250000 new energy automobiles in the province will be popularized and applied, and a pattern of popularization and application that private consumers mainly purchase and make use of new energy automobiles will be formed in 2020. By 2020, there will be 200,000 charging piles built. New energy automobiles, power batteries and key components and parts will have reached the international advanced level as a whole. It is an urgent need for the market to be filled with high-quality applied technical personnel engaged in new energy automobile and parts sales, maintenance and service, diagnosis and repair. Through the enterprise research and expert argumentation, the main jobs of new energy automotive technology include: new energy automobile production, sales and after-sale technical services, that is, production and service lines will be involved in new energy automobile sales, after-sales reception and maintenance, etc. The employment and career development of new energy automobile technology are shown in figure 1.

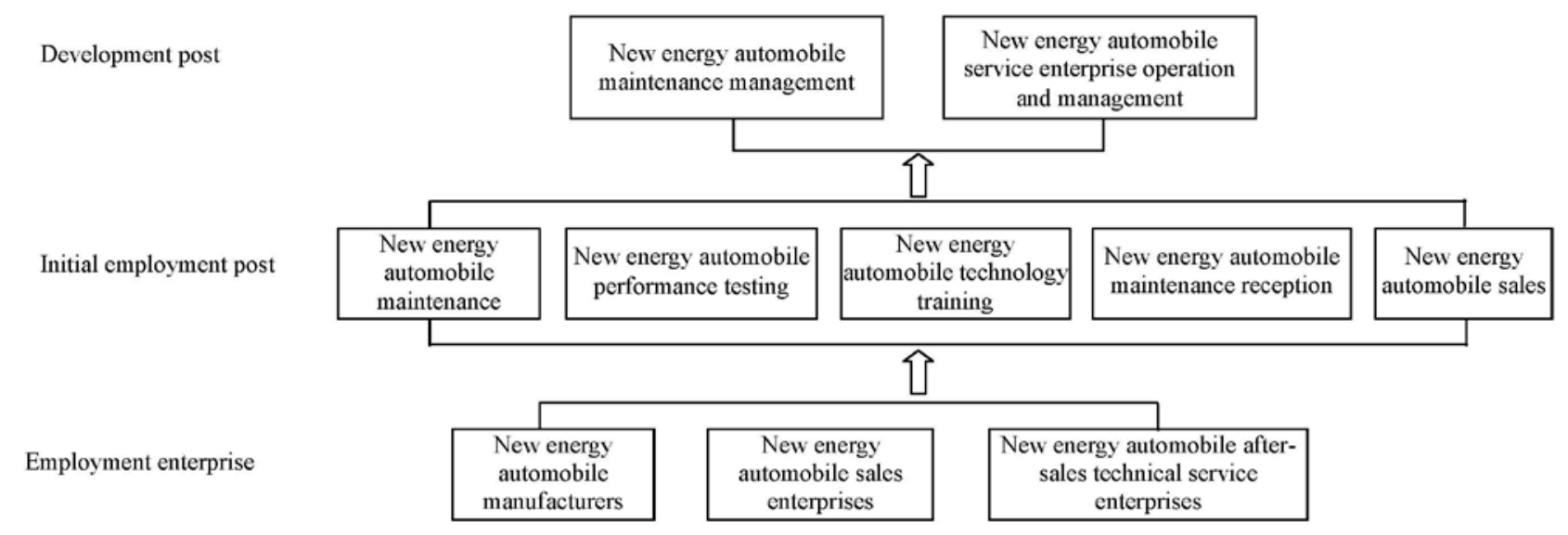

Figure 1 Employment and career development

\section{Talent Training Program Development and Curriculum System Construction}

Combined with the present development trend and personnel demand of new energy automobile industry, through investigation in many ways and repeated demonstration, our school opened the specialty of new energy automotive technology in 2016, and worked out the talent training program and curriculum system. The curriculum system is shown in figure 2. By strengthening professional construction, our school has being built "Chery new energy automobile marketing and after-sale technical service personnel" training base together with Chery New Energy Automotive Technology Co., Ltd. and Wuxi Maoye Education Technology Co., Ltd. In accordance with the personnel training idea of modern apprenticeship, we have built up a talent training program and shall train qualified high-end technical talents for Chery new energy automobile aftermarket.

\section{Construction Content of Chery New Energy Automobile Training Base}

According to the function standards of Chery new energy automobile 4S store, build the training base of "Chery new energy automobile marketing and after-sales technical service personnel". The construction content and functions mainly include four parts :(1) Chery new energy automobile marketing training hall; (2) Chery new energy automobile maintenance training workshop; (3) New 
energy automobile professional education training base; (4) Virtual simulation demonstration hall for new energy automobiles.

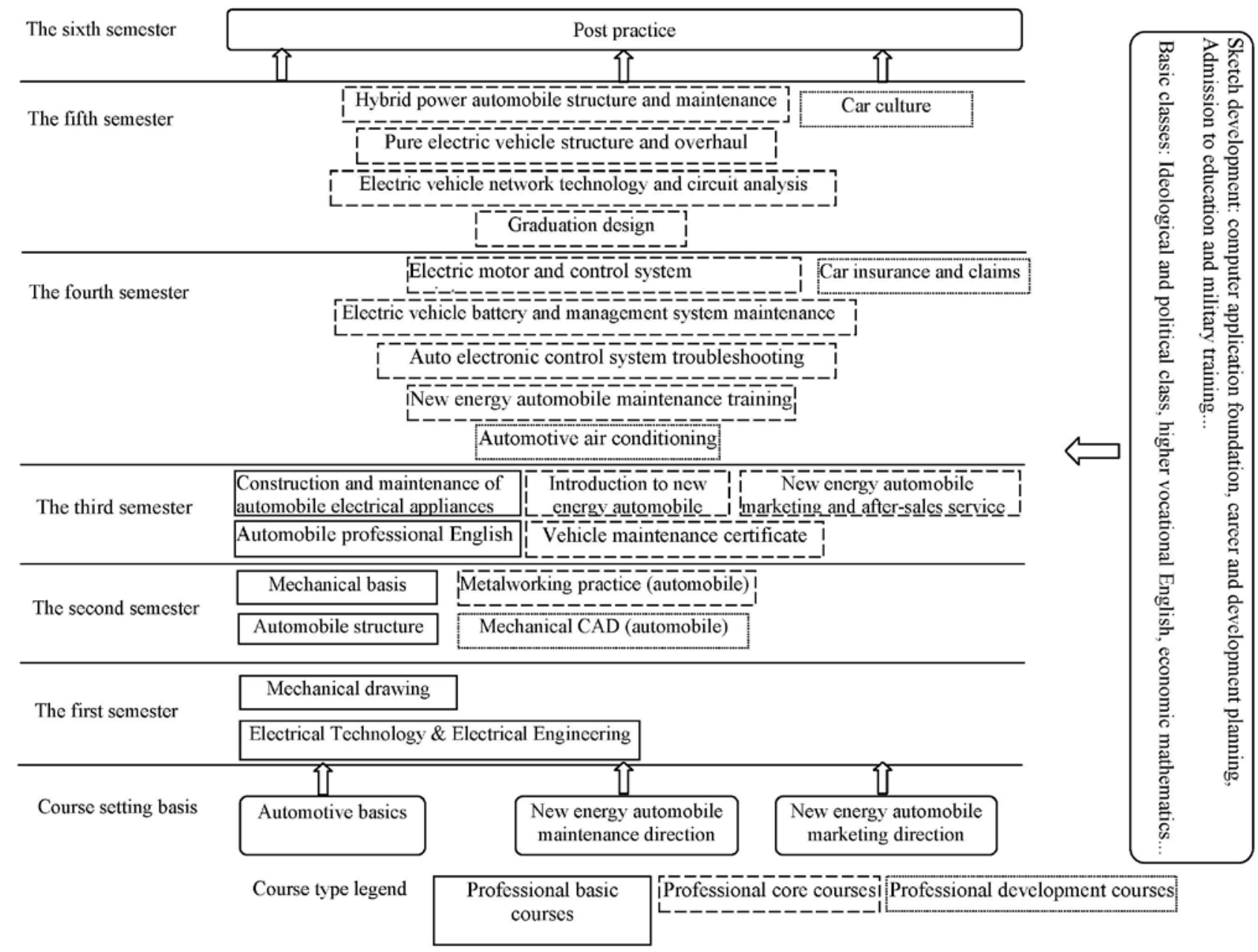

Figure 2 Curriculum system

\section{Conclusion}

University-enterprise cooperation and industry-education integration are the eternal theme of vocational education. The training base of "Chery new energy automobile marketing and after-sale technical service personnel" is based on "talent cultivation, regional employee training, teacher training of cooperating colleges and universities, new energy automobile sales, and new energy automobile after-sale technical service" and many other functions in the whole East China region.

\section{Reference}

[1] Jiang Shaozhong, Yan Wenbing. Discussion on the construction of experimental training center for new energy automobiles in colleges and universities based on applied talent training [J]. Journal of Tianjin University of Technology and Education, 2013, 27(01):14-16.

[2] Feng Yafeng, Liu Guiguang. Discussion on the training mode of new energy automobile professionals in higher vocational colleges [J]. Time Education, 2015(16):83.

[3] Zhou Jingjing. Preliminary exploration on professional curriculum system construction of application and maintenance of new energy automobiles in higher vocational colleges based on SGAVE model [J] Course Education Research, 2017(34):238-239.

[4] Gong Wenjun. Exploration of more options for low-carbon education in the context of low carbon economy -- my view on professional development of vocational education and development 
of professional courses [J]. New Courses' Study (below), 2011 (07):69-70.

[5] Chen Yanyin. Research on the development of new energy automobile industry in China [D] Capital University of Economics and Business, 2017.

[6] Li Suxiu, Liu Yingqi, Wang Jingyu, Zhang Lei. Analysis on the development policy of China's new energy automobile industry based on market performance [J] China Population Resources and Environment, 2016, 26(09):158-166. 